\title{
CASE STUDY: REGIONAL SUPPLY OF FUEL TO CEMENT INDUSTRY - EVALUATION OF A REGIONAL WASTE TREATMENT
}

\author{
Peter Mellbo \\ Kalmarsundsregionens renhållare, KSRR, Sweden
}

\begin{abstract}
In 2005, 49 million tonnes of municipal solid waste (MSW) were incinerated in conventional incineration plants (CWI-plants) in Europe. There are, however, alternatives to treating solid waste in CWI-plants. By treating the solid waste in a mechanical-biological treatment plant (MBT-plant) or in a mechanical treatment plant (MT-plant) the solid waste can be sorted into fractions of combustible matter, inert matter and metals. The sorted combustible matter (refuse-derived fuel, RDF) can be used for co-incineration in e.g. cement kilns. This study comprises an environmental economic evaluation of treatment of solid waste in a CWI-plant or treatment in a MBT-plant or a MT-plant, followed by incineration of produced RDF at a regional cement industry. The evaluation was made with an evaluation method, in which criteria were quantified or valuated. The aim of this study was to identify the economic and environmental effects of a regional treatment of solid waste.

The study shows that a treatment of solid waste in a MT-plant is the best scenario from an environmental economical point of view, while a treatment and incineration in a CWI-plant is the worst scenario. The study clearly shows that KSRR and the environment has a lot to gain if the treatment of solid waste in the future is changed from treatment and incineration in a CWI-plant to a treatment in a MT-plant, where produced RDF is incinerated at the regional cement industry. It also shows that treatment in a MBT-plant or a MT-plant follows the waste hierarchy to a better extent, compared to treatment and incineration in a CWI-plant.
\end{abstract}

\section{KEYWORDS}

Fuel, municipal solid waste (MSW), Refuse-Derived Fuels (RDF), waste hierarchy, sorting.

\section{NOMENCLATURE}

Commercial waste Waste from commercial and industrial sector.

CWI

MBT

MSW

MT

Organic waste

RDF

Conventional waste incineration

Mechanical-biological treatment

Municipal solid waste

Mechanical treatment

Solid waste

Food waste and waste from cooking and kitchens (not garden waste)

Refuse-derived fuel

MSW and commercial waste 


\section{INTRODUCTION}

According to directive 2008/98/EC, of the European parliament, the waste prevention and management shall apply the following waste hierarchy:
(a) prevention;
(b) preparing for re-use;
(c) recycling;
(d) other recovery, e.g. energy recovery
(e) disposal.

Since 2002 it is forbidden in Sweden to put combustible waste in landfills (SFS 2001:512). Therefore municipal solid waste (MSW), which has a composition that does not make it suitable for recycling, is generally incinerated in Sweden, in order to produce hot water for district heating, steam and electricity. In 30 percent of Sweden's municipalities the MSW is sorted in two fractions: organic waste (food waste, kitchen waste) and a combustible fraction [1]. It is rare that the MSW is sorted into more than two fractions in Sweden and the remaining municipalities only have one fraction of MSW, a fraction of mixed organic and combustible waste, which is incinerated [1]. However, solid waste contains more than organic and combustible matter, for example glass and other inert matter, ferrous and non-ferrous metals $[2 ; 3 ; 4]$.

In 2005, 49 million tonnes of MSW were incinerated in conventional waste incineration plants (CWI-plants) in Europe, while approximately 11 million tonnes of MSW were treated in mechanical-biological treatment plants (MBT-plants) or mechanical treatment plants (MTplants) [5].

There are two main technologies for incineration in CWI-plants: grate fired incineration and fluidized bed incinerations. Grate fired incineration is worldwide, the most common technology for waste incineration. The waste is combusted on a moving grate and the system has the benefit of robustness towards heterogeneities in the waste. Generally the waste enters the furnace as received, however sometimes large items are shredded before entering the furnace. The grate fired incineration plants exist in many sizes and configurations, treating from a few tonnes of waste per hour up to about 40 tonnes per hour, of both mixed MSW and industrial waste. In the fluidized bed incinerators the waste is kept in motion inside the furnace and a bed material, such as sand, is used to support the heat transfer to the waste. The waste often has to be pre-treated (shredded) when combusted in a fluidized bed incinerator, because the incinerator demands a more homogenous fuel compared to the grate fired incinerators. However, the fluidized bed incinerators may enable more efficient energy recovery compared to grate fired incinerators. [2]

Incineration of solid waste, both in grate fired and fluidized bed boilers, produces slags and ashes, formed by inorganic content in the waste [6]. Bottom ash and slags are solid residues formed in the combustion chamber, while fly ash is particles separated in the flue gas cleaning equipment [6]. Fly ash is generally not utilized, while the bottom ash is utilized in many countries, in order to save natural aggregates [2;7]. Bottom ash can for example, be used for road construction [2]. The fly ash is often placed in a landfill, which in the future could lead to leakage of hazardous substances, for example heavy metals, to the surrounding environment [8].

An alternative to incineration of the solid waste in a CWI-plant is to sort the waste in a MBTplant or in a MT-plant into fractions of refuse-derived fuel (RDF), inert matter and metals. The RDF comprises materials such as non-recyclable plastics, wood, paper, textiles and cardboard sorted from MSW or industrial waste and can be used for co-combustion in power plants or industrial facilities, such as cement kilns [2]. Ash from combustion of RDF in 
cement kiln is included in clinker production [3;9] and therefore no ash is generated in the process. Cement production requires incineration at high and stable temperatures (approximately $1450^{\circ} \mathrm{C}$ ) with long process times and high levels of oxygen and is therefore suitable for incineration of waste $[9 ; 10]$.

Kalmarsundsregionens renhållare (KSRR) is a municipal association formed in 2006 whose tasks are planning, collection and treatment of household waste [11]. KSRR was founded by four Swedish member municipalities: Kalmar, Mörbylånga, Nybro and Torsås municipalities (see Figure 1) [11]. KSRR's geographical area is $3280 \mathrm{~km}^{2}$ and has approximately 102000 inhabitants [12]. At present, the solid waste from KSRR is incinerated in a CWI-plant without any separation of organic waste. However, from the end of 2011 the solid waste within KSRR will be sorted into two fractions at the customer's site; one fraction of organic waste and one fraction of combustible waste. The separation of organic and combustible waste opens the

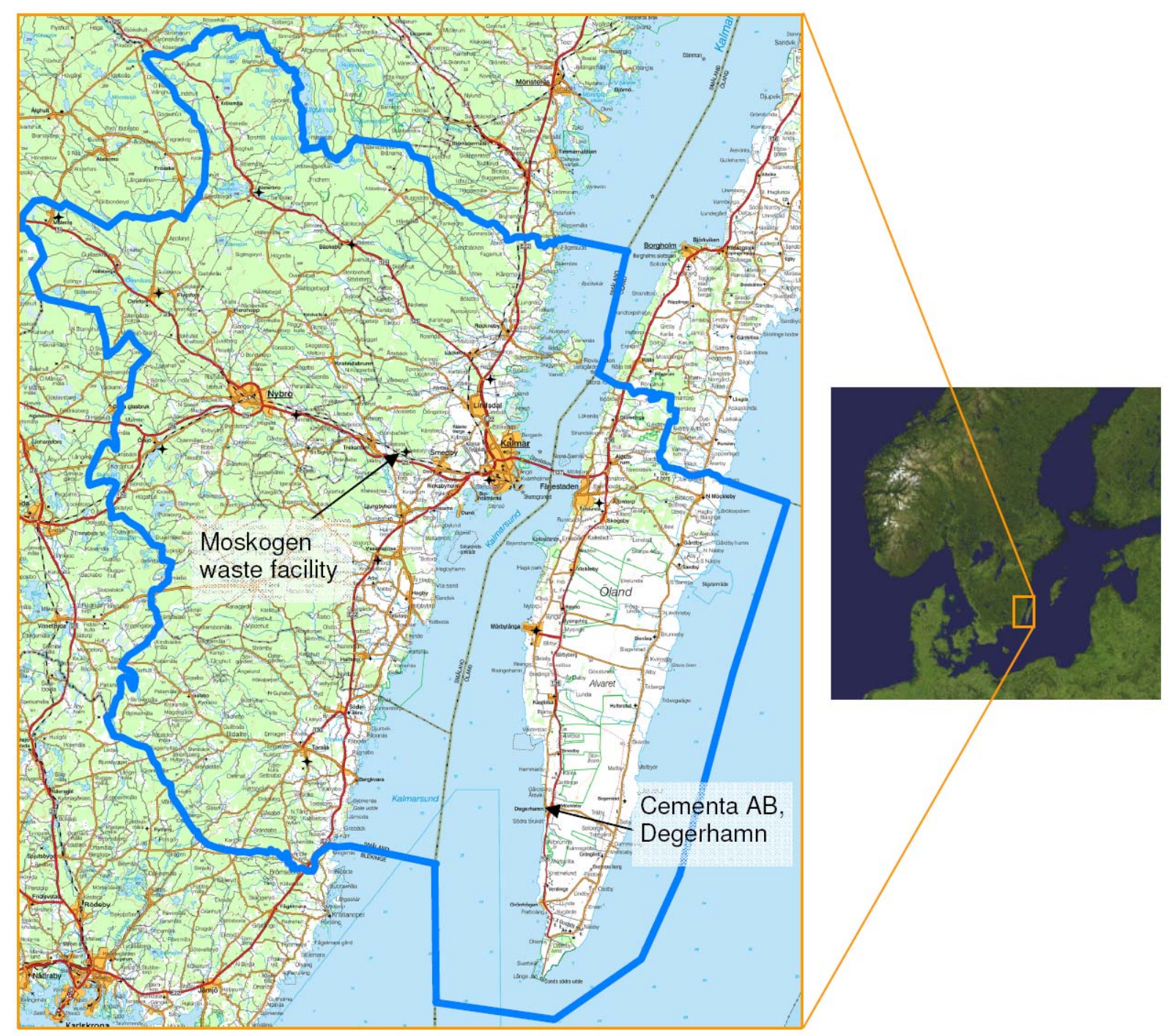

Figure 1. The geographical area of KSRR and the location of Moskogen waste facility and Cementa AB, Degerhamn, in the south-east part of Sweden. 
possibility of treating the combustible waste in a MBT-plant or a MT-plant, in order to produce a RDF fraction.

This study comprises an environmental economic evaluation of treatment of solid waste in a CWI-plant or treatment in a MBT-plant or a MT-plant, followed by incineration of produced RDF at a regional cement industry. The aim of this study was to identify the economic and environmental effects of a regional treatment of solid waste.

\section{METHOD}

The evaluation of the scenarios was based on a valuation method described in Jonerholm, Millers-Dalsjö \& Rönnols [13], however the method has been revised by the author. The method was primarily developed by Jonerholm, Millers-Dalsjö \& Rönnols [13], from LCAmethods and methods of investigation to find locations for new facilities.

At first, scenarios describing the different situations and alternatives to be evaluated are drawn up. Then, the criteria are established. The criteria are then used to evaluate the scenarios.

The criteria were quantified where it was possible (for example cost in SEK or emission of $\mathrm{CO}_{2}$ ). However, some criteria cannot be quantified and these are instead compared and valuated. These criteria are ranked from $1-5$, where 1 is the poorest value and 5 is the best value.

In order to compare the criteria in the different scenarios the quantified or valuated value of the criterion must be standardized. Negative quantified criteria were standardized by dividing the lowest value in all scenarios by the actual value of the scenario. Positive quantified criteria were standardized by dividing the actual value of the scenario by the highest value in all scenarios. The standardization of the valuated values was done by dividing the actual value of the scenario with the highest value (5).

Negative quantified criterion is defined as a criterion where a high value is considered to have a negative impact on the scenario (e.g. costs). A positive quantified criterion is defined as a criterion where a high value is considered to have a positive impact on the scenario (e.g. "Reduced need of landfill sites").

Each criterion was given an importance factor and the sum of the importance factors for all criteria shall be $1.0(100 \%)$. The standardized value multiplied by the importance factor of the criterion gives the score of the criterion. The score from each criterion was summarized to a total score of the scenario. A high total score means a good scenario and if one scenario had been best in all criteria it would attain the total score of 1.0.

The total score of the scenarios is the result of the evaluation, and indicate the differences in environmental and economical effects between the scenarios, with the intention of comparing them to each other.

Three different treatment plants have been used as three different scenarios in order to evaluate the environmental economical effects of a regional waste treatment. 


\subsection{Conventional waste incineration plant (CWI-plant)}

At present, KSRR sends all solid waste, both organic and combustible, by lorry for incineration at a CWI-plant located at a distance of $255 \mathrm{~km}$ from KSRR's waste facility. The CWI-plant is equipped with a CFB-boiler (Circulating Fluid Bed) operating at approximately $850^{\circ} \mathrm{C}$, incinerating MSW, commercial waste and sewage sludge. The waste is pre-shredded at the CWI-plant and ferrous metals are removed with magnet, before incineration.

\subsection{Mechanical-biological treatment plant (MBT-plant)}

In the MBT-plant the solid waste is pre-shredded and dried in a biological process (aerobic degradation). The drying of the solid waste increases the calorific value and increases the possibilities of storing the material (without biological activity and mould). After drying, the solid waste is sorted by air-separators and sieving processes, into fractions of RDF, inert matter and metals. The metal fraction is recycled and the fraction of inert material (such as glass and porcelain) can be recycled e.g. as a ground construction material [14]. The heat value of the produced RDF has been reported to be up to $20 \mathrm{MJ} / \mathrm{kg}$, with a mean value of around $19 \mathrm{MJ} / \mathrm{kg}[2 ; 15]$.

Produced RDF in this scenario is transported by lorry to a regional cement industry, located $63 \mathrm{~km}$ from KSRR's waste facility (see Figure 1).

\subsection{Mechanical treatment plant (MT-plant)}

The first process step in the MT-plant is pre-shredding of the solid waste. After shredding magnets and eddy-current separators remove metals from the waste. The remaining waste is screened and then sorted by a ballistic separator, where the waste is separated depending on density, resulting in a light fraction (the RDF) and a heavy fraction (the inert matter). As in the MBT-plant the metals are recycled and the inert matter can be recycled e.g. as a ground construction matter. The produced RDF from this plant can be expected to have a heat value of approximately $17 \mathrm{MJ} / \mathrm{kg}[15]$.

Produced RDF in this scenario is transported by lorry to a regional cement industry, located $63 \mathrm{~km}$ from KSRR's waste facility (see Figure 1).

\subsection{System limits}

Transports included in the study only designates transport from KSRR's waste facility to the incineration plant (CWI-plant or cement industry), collection of the waste is not included. In this study the environmental effects are limited to only include emissions of the greenhouse gas $\mathrm{CO}_{2}$. Transports in the scenarios with the MBT-plant and the MT-plant only include transports of the produced RDF, because of the uncertainty of where the other fractions will be delivered and recycled. 


\section{RESULTS AND DISCUSSION}

The results of the evaluation (see Table 1 and Figure 2) indicate that the scenario where the waste is treated in a MT-plant, and the produced RDF is incinerated at the regional cement industry, is the best scenario with regard to the environmental economic issue. The least favourable scenario is treatment in the CWI-plant, which has poor effects on both economy and environment.

The scenario with the MT-plant has the best result in "Economy", due to the lowest costs of transport and treatment. The MBT-plant shows a better result regarding "Economy" compared to the CWI-plant. However, out of all three scenarios the MBT-plant has the highest treatment cost per tonne waste. It is due to the lower transport cost compared to the CWI-plant scenario

Table 1. The environmental economic evaluation of the different scenarios.

\begin{tabular}{|c|c|c|c|c|c|c|c|c|c|c|c|}
\hline & \multirow{2}{*}{\multicolumn{2}{|c|}{ Treatment plant }} & \multicolumn{3}{|c|}{ CWI-plant } & \multicolumn{3}{|c|}{ MBT-plant } & \multicolumn{3}{|c|}{ MT-plant } \\
\hline & & & \multicolumn{3}{|c|}{ Standardized Score } & \multicolumn{3}{|c|}{ Standardized Score } & \multirow[t]{2}{*}{ Value } & Standardized & \multirow[t]{2}{*}{ Score } \\
\hline Criterion & Unit & Importance & & & & & & & & & \\
\hline Effect on climate & & $25 \%$ & & & & & & & & & \\
\hline EmIssion of $\mathrm{CO}_{2}$ trom transport & $\mathrm{Kg} \mathrm{CO}_{2}$ /tonne waste & 0,08 & 29,2 & 0,22 & 0,017 & 11,0 & 0,57 & 0,046 & 11,0 & 0,57 & 0,046 \\
\hline Emission of $\mathrm{CO}_{2}^{2}$ from treatment plant & $\mathrm{kg} \mathrm{CO}_{2} /$ tonne waste & 0,08 & 1,87 & 1,00 & 0,080 & 5,33 & 0,35 & 0,028 & 3,46 & 0,54 & 0,043 \\
\hline Climate ambition Cementa $\mathrm{AB}$ and KSRR & $1-5$ & 0,04 & 1 & 0,20 & 0,008 & 3 & 0,60 & 0,024 & 2 & 0,40 & 0,016 \\
\hline Climate ambition in Kalmar county & $1-5$ & 0,05 & 1 & 0,20 & 0,010 & 5 & 1,00 & 0,050 & 4 & 0,80 & 0,040 \\
\hline Natural resources & & $10 \%$ & & & & & & & & & \\
\hline Need of facilities & $1-5$ & 0,03 & 4 & 0,80 & 0,024 & 2 & 0,40 & 0,012 & 3 & 0,60 & 0,018 \\
\hline Degree of recycling & $1-5$ & 0,04 & 2 & 0,40 & 0,016 & 3 & 0,60 & 0,024 & 3 & 0,60 & 0,024 \\
\hline Residue to landfill & tonne/year & 0,03 & 3072 & 0,0003 & 0,000 & 1 & 1,00 & 0,030 & 1 & 1,00 & 0,030 \\
\hline Energy & & $15 \%$ & & & & & & & & & \\
\hline Heat value in waste/RDF & GJ/tonne & 0,075 & 12 & 0,63 & 0,047 & 19 & 1,00 & 0,075 & 17 & 0,89 & 0,067 \\
\hline Energy balance & GJ & 0,075 & 325784 & 0,89 & 0,067 & 365654 & 1,00 & 0,075 & 329348 & 0,90 & 0,067 \\
\hline Effects on the surroundings & & $5 \%$ & & & & & & & & & \\
\hline Odour & $1-5$ & 0,01 & 2 & 0,40 & 0,004 & 5 & 1,00 & 0,010 & 4 & 0,80 & 0,008 \\
\hline Litter & $1-5$ & 0,01 & 2 & 0,40 & 0,004 & 4 & 0,80 & 0,008 & 4 & 0,80 & 0,008 \\
\hline Traffic safety & $1-5$ & 0,03 & 1 & 0,20 & 0,006 & 2 & 0,40 & 0,012 & 2 & 0,40 & 0,012 \\
\hline Pedagogic effect & & $5 \%$ & & & & & & & & & \\
\hline Waste hierarchy & $1-5$ & 0,01 & 2 & 0,40 & 0,004 & 3 & 0,60 & 0,006 & 3 & 0,60 & 0,006 \\
\hline Regional treatment & $1-5$ & 0,01 & 1 & 0,20 & 0,002 & 5 & 1,00 & 0,010 & 5 & 1,00 & 0,010 \\
\hline Replacement of fossil fuels & tonne $\mathrm{CO}_{2} /$ year & 0,02 & 1 & 0,00004 & 0,000 & 24872 & 1,00 & 0,020 & 22254 & 0,89 & 0,018 \\
\hline Reduced need of landfill sites & tonne/year & 0,01 & 1 & 0,0003 & 0,000 & 3072 & 1,00 & 0,010 & 3072 & 1,00 & 0,010 \\
\hline Economy & & $30 \%$ & & & & & & & & & \\
\hline Treatment cost & SEK/tonne waste & 0,15 & 575 & 0,52 & 0,079 & 636 & 0,47 & 0,071 & 301 & 1,00 & 0,150 \\
\hline Transport cost & SEK/tonne & 0,15 & 197,3 & 0,41 & 0,061 & 80 & 1,00 & 0,150 & 80 & 1,00 & 0,150 \\
\hline Treatment plant & & $10 \%$ & & & & & & & & & \\
\hline Flexibility in treatment capacity & $1-5$ & 0,10 & 5 & 1 & 0,100 & 1 & 0,2 & 0,020 & 3 & 0,6 & 0,060 \\
\hline Total & & & & & 0,53 & & & 0,68 & & & 0,78 \\
\hline
\end{tabular}

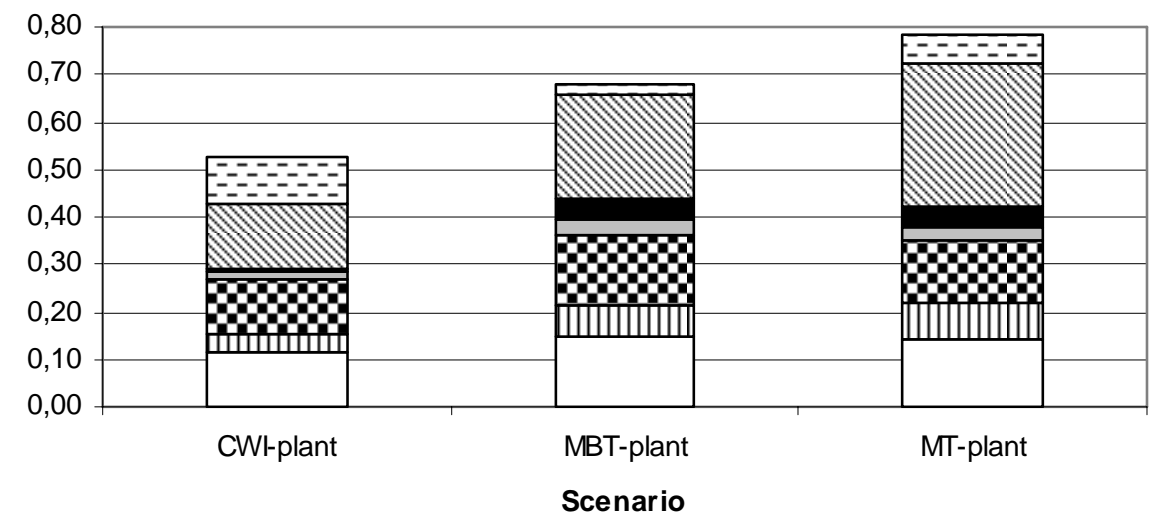
$\square$ Effect on climate
๓ Natural resources
๑ Energy
$\square$ Effects on the surroundings
Pedagogic effect
Q Economy
๑ Treatment plant

Figure 2. Results from the environmental economic evaluation. 
that the MBT-plant scenario shows a better result in "Economy". Emissions of $\mathrm{CO}_{2}$ from treatment are higher in the MBT- and MT-plant, but the shorter transport distance results in emission savings compared to the scenario with the CWI-plant. This results in higher scores in the criterion "Effect on climate" for the scenario with the MBT- and MT-plant, compared to the scenario with the CWI-plant. The MBT-plant has a slightly better result in the "Effect on climate" and "Energy" compared to the MT-plant, due to a higher heat value of the produced RDF. The flexibility in the treatment plant is best in the CWI-plant, while the MBTplant has the lowest flexibility in treatment capacity.

The results clearly indicate that the scenario that KSRR uses today, incineration of unsorted solid waste in a CWI-plant, is not the best alternative regarding environment and economy. In the future both KSRR and the environment would benefit from changing the treatment scenario of the solid waste, from treatment and incineration in a CWI-plant to a treatment of solid waste in a MT-plant or a MBT-plant, and produce a RDF fraction for incineration at a regional cement industry. The regionally produced RDF can replace fossil fuel (such as coal) or imported RDF in the cement production, and thereby reduce the emission of fossil $\mathrm{CO}_{2}$ from fossil fuels and from transports.

Not only the municipalities and the environment benefits from a regional treatment and incineration of solid waste. Depending on the cement plant configuration RDF can generally cover $30-60 \%$ of the total heat demand. The regionally produced RDF from KSRR can cover up to $32 \%$ of the regional cement industry's heat demand and to some extent reduce costs for the cement industry.

The European directive 2008/98/EC calls for the implementation of the waste hierarchy. A waste treatment plant such as a MBT-plant or a MT-plant, where the waste is sorted into fractions of combustible matter (the RDF fraction), inert matter and metals, allows a bigger portion of recycling of materials compared to a treatment in a CWI-plant, where the inert matter and some of the metal fraction also are incinerated. This leads to the conclusion that the MBT-plant and the MT-plant follows the waste hierarchy more than treatment and incineration in a CWI-plant. Sorting out the inert matter and the metals has several advantages: it generally increases the heat value and it substantially reduces the ash content of the produced RDF. Reduced ash content also means reduced amounts of ash, which will lead to less need of landfill areas for waste incineration ashes. However, sorting out the inert matter from the RDF and incinerating the RDF in a cement kiln reduces the need of landfill areas for ashes to zero, since the small amount of ash produced in the cement kilns is included in the clinker production.

The Swedish Waste Management [16] has shown that import of combustible waste (e.g. MSW) to Sweden and incineration of the imported waste in CWI-plants can be environmentally beneficial, when compared to landfilling in the country of origin. The conclusion made by the Swedish Waste Management [16] is correct, since landfilling is, environmentally, an alternative worse than incineration $[17 ; 18]$. However, the Swedish Waste Management [16] completely forgets to raise the issue of a regional treatment and incineration of the combustible waste. A regional treatment of the combustible waste can be better than an export of the combustible waste - since it involves shorter transports. A sorting of the combustible waste, where the inert matter is separated from the combustible matter, is even more beneficial if the waste is to be transported long distances before incineration. Thereby, transportation of smaller amounts will be necessary, however with similar total heat value. 


\section{CONCLUSIONS}

This study indicates that sorting the combustible waste into a RDF fraction and deliver the RDF to a regional cement industry is a better alternative from an environmental economic point of view than incinerating the waste in a CWI-plant.

The best scenario is the treatment of solid waste in a MT-plant.

The least favourable scenario is the treatment of solid waste in a CWI-plant, indicating that KSRR and the environment has a lot to benefit from changing the treatment of solid waste to treatment in a MT-plant, producing RDF to the regional cement industry.

The scenarios with treatment of solid waste in a MBT-plant or a MT-plant follow the waste hierarchy to a larger extent compared to the scenario with treatment of solid waste in a CWIplant, resulting in an RDF fraction with higher heat contents and in bigger amounts of inert matter and metals for recycling.

The regional produced RDF from solid waste can cover up to $30 \%$ of the total heating requirement in the regional cement industry.

\section{ACKNOWLEDGEMENTS}

The financial support from The Regional Council in Kalmar county is gratefully acknowledged.

\section{REFERENCES}

[1] Swedish Waste Management, 2007. Insamling och behandling av hushållsavfall Former och utförande samt ekonomiska effekter på avfallsavgifterna. Report 2007:05. ISSN 1103-4092. (In Swedish)

[2] Astrup, T., Møller, J., Fruergaard, T., 2009. Incineration and co-combustion of waste: accounting of greenhouse gases and global warming contributions. Waste Management \& Research, 27, 789-799.

[3] Papageorgiou, A., Karagiannidis, A., Barton, J.R., Kalogirou, E., 2009. Municipal solid waste management scenarios for Attica and their greenhouse gas emission impact. Waste Management \& Research, 27, 928-937.

[4] Vukicevic, S., Lewis-Jonsson, L., 2009. Plockanalys av hushållens restavfall i Växjö. Helsingborg: NSR Forskning och Miljö. (In Swedish)

[5] Swedish Waste Management, 2009. Energy from waste - An international perspective. Report U2009:05. ISSN 1103-4092.

[6] Sundqvist, J.-O., 1999. Life cycle assessments and solid waste - Guidelines for solid waste treatment and disposal in LCA. AFR-Report 279. Stockholm: Swedish Environmental Protection Agency.

[7] Astrup, T., 2007. Pretreatment and utilization of waste incineration bottom ashes: Danish experiences. Waste Management, 27, 1452-1457.

[8] Crawford, J.N., 1996. The long term release of heavy metals from combustion residues and slags. Lic. Thesis, Royal Institute of Technology, KTH. AFR-report 148. Stockholm: Swedish Environmental Protection Agency.

[9] Cementa, 2008. Hållbarhetsredovisning 2007 Vårt ansvar - att bygga för framtiden. Stockholm: Cementa AB. (In Swedish)

[10] Gillberg, B., 1999. Betongen i kretsloppssamhället. In Gillberg, B., Fagerlund, G., Jönsson, Å., Tillman, A.-M., 1999. Betong och miljö - Fakta från Betongforum. Trelleborg: Svensk Byggtjänst. (In Swedish)

[11] KSRR, 2008a. Avfallsplan 2009-2012, del 1. Kalmar: Kalmarsundsregionens renhållare. (In Swedish) 
[12] KSRR, 2008b. Avfallsplan 2009-2012, del 2. Kalmar: Kalmarsundsregionens renhållare. (In Swedish)

[13] Jonerholm, K., Millers-Dalsjö, D., Rönnols, E., 2008. KSRR Miljövärdering Insamling och behandling av utsorterat matavfall. Stockholm: SWECO VIAK. (In Swedish)

[14] Herhof, 2007. Clean energy from waste. Solms-Niederbiel: Herhof GmbH.

[15] Mellbo, P., 2010. Regional and Climate Efficient Waste Management - an Environmental Economic Evaluation of Transport and Treatment of Combustible Waste. Kalmar: Kalmarsundsregionens renhållare.

[16] Swedish Waste Management, 2010. Import of combustible waste and its impact on emissions of climate gases. Report U2010:01. ISSN 1103-4092.

[17] Christensen, T.H., Simion, F., Toini, D., Møller, J., 2009. Global warming factors medelled for 40 generic municipal waste management scenarios. Waste management \& Research, 27, 871-884.

[18] Ragossnig, A.M., Wartha, C., Pomberger, R., 2009. Climate impact analysis of waste treatment scenarios - thermal treatment of commercial and pretreated waste versus landfilling in Austria. Waste management \& Research, 27, 914-921. 